\title{
ROŚLINY TRUJĄCE I LECZNICZE MIASTA POŁCZYN-ZDRÓJ I JEGO OKOLIC (POJEZIERZE DRAWSKIE) - BADANIA WSTĘPNE
}

\author{
PATRYCJA RADKE
}

Uniwersytet Szczeciński, Katedra Botaniki i Ochrony Przyrody, ul. Felczaka 3C, 71-412 Szczecin, e-mail: patrycjaradke7@gmail.com

\begin{abstract}
Preliminary studies on medicinal and poisonous plants of Połczyn-Zdrój and the surrounding area were conducted in 2015. These studies showed the presence of 69 species, including highly toxic species such as: Datura stramonium L., Convallaria majalis L., Aconitum variegatum L. and Papaver somniferum L.
\end{abstract}

Keywords: flora, poisonous vascular plants, vicinity of settlements, Western Pomerania, Poland

\section{WSTĘP}

Rośliny lecznicze w medycynie ludowej stosowane są od bardzo dawna (Ożarowski, Jaroniewski 1987). Niektóre zioła były znane i używane w różnego typu schorzeniach już w starożytności, np. Silybum marianum w zapobieganiu i leczeniu chorób wątroby i pęcherzyka żółciowego (Morazzoni, Bombardelli 1995). Zawierają one substancje biologicznie czynne, które mają właściwości antyoksydacyjne. Związki te są zdolne do neutralizowania wolnych rodników wytwarzanych przez organizm człowieka, których nadmiar jest częstą przyczyną wielu schorzeń (Sies 1991). Substancje biologicznie czynne zawarte w ziołach są bezpieczniejsze od syntetycznych, gdyż powodują mniejsze efekty uboczne (Sen $\mathrm{i}$ in. 2010). $Z$ tego względu naturalna medycyna, jako wspomagająca główny proces terapeutyczny, przeżywa obecnie renesans. Zioła budzą powszechne zainteresowanie także w społecznościach lokalnych. Nie tylko są uprawiane, ale również pozyskiwane z miejsc ich naturalnego występowania. Jednak mogą one działać na organizm szkodliwie, gdy są nadużywane. Obok roślin leczniczych występuje wiele gatunków trujących, zawierających substancje toksyczne, do których należą m.in.: skopolamina, hioscyjamina, atropina w Datura stramonium, glikoalkaloidy w Solanum nigrum, akonityna w Aconitum variegatum i wiskotoksyna w Viscum album (Henneberg, Skrzydlewska 1984; Burda 1998). Niekiedy dochodzi do przypadkowych zatruć, np. w wyniku pomylenia gatunku trującego z pozyskiwanym w celach konsumpcyjnych. 
Z powyższego wynika, że w poznawaniu flory określonego obszaru ważnym elementem, obok gatunków rzadkich, zagrożonych i chronionych, są gatunki lecznicze i trujące. Powszechność ich występowania oraz bezproblemowy dostęp do nich powodują, że bardzo istotne jest stwierdzenie ich obfitości na danym terenie.

Celem pracy było poznanie rozmieszczenia oraz określenie zasobów roślin leczniczych i trujących na terenie miasta Połczyn-Zdrój i jego najbliższych okolic.

\section{TEREN I METODY BADAŃ}

Połczyn-Zdrój to miasto uzdrowiskowe położone na Pomorzu w powiecie świdwińskim, w województwie zachodniopomorskim. Według Kondrackiego (2002) należy do Podprowincji Pojezierza Południowobałtyckie, Makroregionu Pojezierza Zachodniopomorskie i Mezoregionu Pojezierze Drawskie. Miasto leży w dorzeczu Parsęty nad rzeką Wogrą. Krajobraz został tam ukształtowany głównie przez ostatnie zlodowacenie, którego pozostałością są liczne moreny oraz oczka polodowcowe. W dorzeczu Parsęty występują zbiorniki wód podziemnych pochodzące z czwartorzędu. Na terenie Połczyna-Zdroju znajdują się źródła solanki z okresu jury i kredy oraz bogate złoża borowiny. W pokrywie glebowej przeważają gleby brunatne, bielicowe i rdzawe (Borówka 2002). Klimat jest chłodny, wilgotny, z długim okresem przymrozków, co skraca okres wegetacji roślin, który wynosi około 212 dni. Średnia roczna suma opadów atmosferycznych kształtuje się na poziomie $700 \mathrm{~mm}$, przy czym najwięcej opadów odnotowuje się w lipcu $(80 \mathrm{~mm})$ i sierpniu $(70 \mathrm{~mm})$. Średnia roczna temperatura powietrza wynosi około $7,5^{\circ} \mathrm{C}$. Najcieplejszym miesiącem jest lipiec (średnia $17^{\circ} \mathrm{C}$ ), a najzimniejszym styczeń $\left(-2,0^{\circ} \mathrm{C}\right.$; Koźmiński i in. 2007).

Badaniami objęto grupę roślin leczniczych i trujących, wyodrębnionych na podstawie prac Mowszowicza $(1982,1990)$ oraz Ożarowskiego i Jaroniewskiego (1987). Eksploracje florystyczne realizowano od marca do października 2015 r. metodą marszrutową. Prowadzone były one na terenie miasta Połczyn-Zdrój oraz obszarów do niego przyległych, w tym okolic wsi Kołacz, Ogartowo i Popielawy (ryc. 1). W badaniach uwzględniono wszystkie znajdujące się na tym terenie ekosystemy lądowe. Rośliny oznaczono na podstawie klucza Rutkowskiego (2004), a nazwy gatunków przyjęto za Mirkiem i in. (2002). Dokumentację zielnikową złożono w Herbarium Stetinensis (SZUB), przy Katedrze Botaniki i Ochrony Przyrody Uniwersytetu Szczecińskiego.

Listę gatunków sporządzono według rodzin ułożonych alfabetycznie (Rutkowski 2004). W wykazie zastosowano następującą kolejność: nazwa łacińska gatunku, określenie czy roślina należy do leczniczych czy trujących, lokalizację 


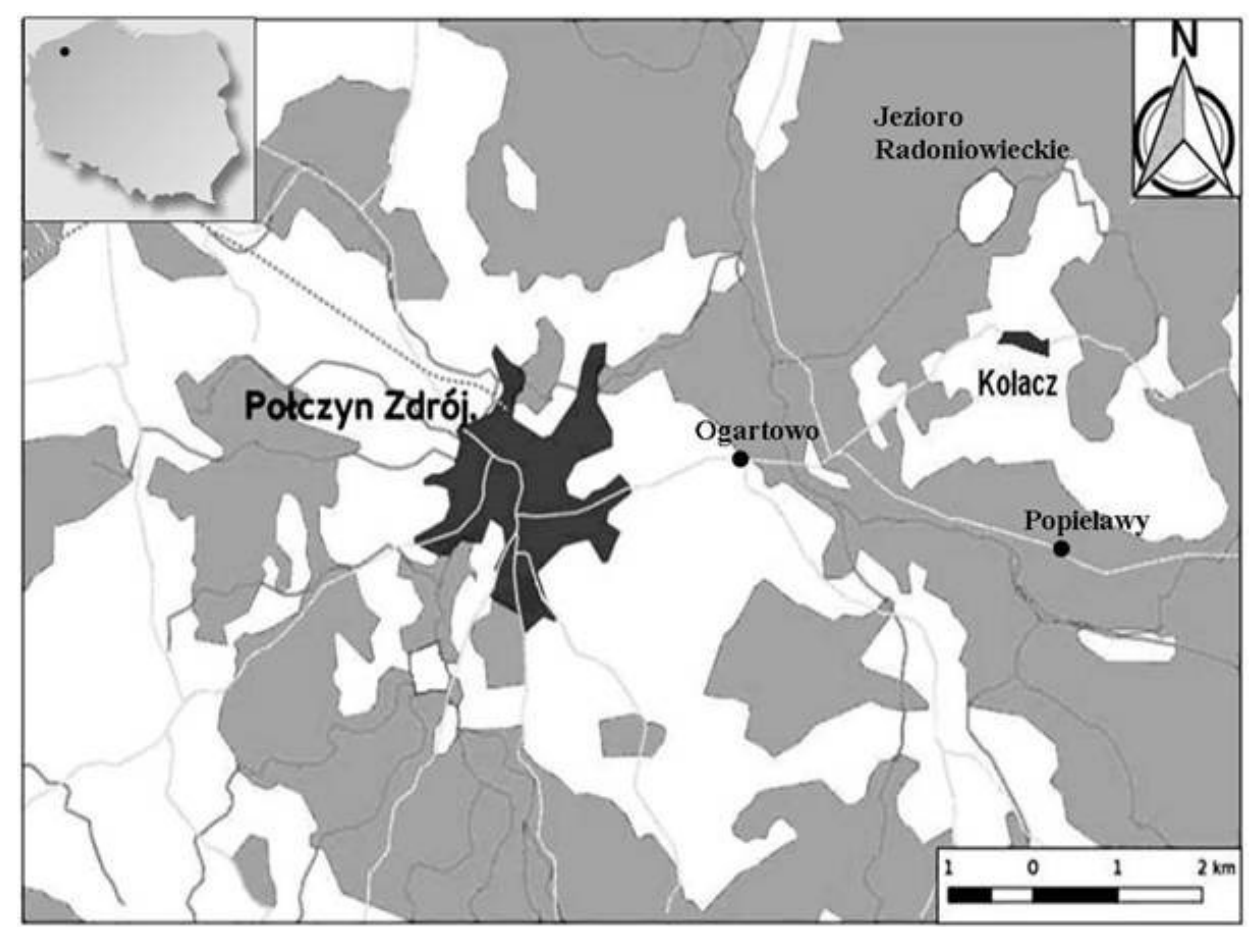

Ryc. 1. Teren badań na obszarze gminy Połczyn-Zdrój

Fig. 1. Map of the research area within the municipality Połczyn-Zdrój

stanowisk, siedlisko i liczebność osobników. Przyjęte skróty: L - roślina lecznicza, $\mathbf{T}$ - roślina trująca, E - wschód, SE - południowy wschód, S - południe, SW - południowy zachód, W - zachód, k. - koło, os - osiedle.

\section{WYNIKI}

Na badanym terenie stwierdzono ogółem 69 gatunków roślin naczyniowych zaliczanych do roślin trujących i leczniczych. Występowały one głównie w południowo-wschodnich i wschodnich obrzeżach miasta Połczyn-Zdrój oraz na obszarach bezpośrednio do nich przyległych. Największą grupę - 30 taksonów, stanowiły rośliny o właściwościach wyłącznie leczniczych, prawie równie licznie, bo przez 28 taksonów reprezentowane były rośliny o właściwościach zarówno leczniczych, jak i trujących, a tylko 11 gatunków było wyłącznie trujących. Spośród odnotowanych taksonów jeden - Agrostemma githago jest ujęty w polskiej czerwonej liście paprotników i roślin kwiatowych w kategorii NT (bliski zagrożenia; Kaźmierczakowa i in. 2016), a Aconitum variegatum objęty jest ochroną częściową (Rozporządzenie Ministra..., 2014). 


\section{Apiaceae}

Aegopodium podagraria L. - L, Połczyn-Zdrój (część SE), pobocze drogi przy ogródkach działkowych, park zdrojowy (część NE), dość licznie; przy drogach: między Połczynem-Zdrojem a Kołaczem i Połczynem-Zdrojem a Popielawami; skraje lasów koło Kołacza, licznie.

\section{Apocynaceae}

Vinca minor L. - L, T, Połczyn-Zdrój, trawnik przy liceum ogólnokształcącym, ul. Staszica, trzy osobniki.

\section{Asteraceae}

Achillea millefolium L. - L, Połczyn-Zdrój (część E i SE); k. Jeziora Radoniowieckiego, miedze, ugory, łąki, licznie.

Arctium lappa L. - L, Połczyn-Zdrój, skraj drogi przy ogródkach działkowych, łąki na obrzeżach miasta, dość licznie.

Artemisia absinthium L. - L, T, na W od Kołacza, poręba, 4 osobniki.

Artemisia campestris L. - L, T, na N od Kołacza, łąka, 3 osobniki; Połczyn-Zdrój (część SE), łąka przy os. Polna, 4 osobniki.

Artemisia vulgaris L. - L, T, na W od Kołacza, poręba, 2 osobniki; na N od Kołacza, łąka, 9 osobników; Połczyn-Zdrój (część SE), łąka przy os. Polna, ogródki działkowe, obrzeża miasta, ugory, licznie.

Bellis perennis L. - L, Połczyn-Zdrój, trawniki, park zdrojowy, ogródki działkowe, bardzo licznie; na N od Kołacza, łąki, bardzo licznie.

Centaurea cyanus L. - L, Połczyn-Zdrój (część SE), pole uprawne, licznie.

Chamomilla recutita (L.) Rauschert - L, Połczyn-Zdrój (część SW), pole uprawne, licznie.

Chamomilla suaveolens (Pursch) Rydb. - L, Połczyn-Zdrój, pobocza przy ulicach Strażackiej, Polnej, Młyńskiej, przy ogródkach działkowych, stadion sportowy, licznie; na W od Kołacza, brzeg drogi do Jeziora Radoniowieckiego, dość licznie.

Cichorium intybus L. - L, Połczyn-Zdrój (część E), wysypisko śmieci między cmentarzem komunalnym a stadionem miejskim, pobocza przy ul. Strażackiej, pojedyncze osobniki.

Conyza canadensis (L.) Cronquist - L, Połczyn-Zdrój, nasyp kolejowy, wysypisko śmieci między cmentarzem komunalnym a stadionem miejskim; droga na E od Połczyna-Zdroju w kierunku Ogartowa, droga między Ogartowem a Popielawami na S od Kołacza, licznie.

Petasites hybridus (L.) P. Gaertn., B. Mey \& Scherb. - L, Połczyn-Zdrój, przy ul. Gwardii Ludowej, 2 osobniki; pobocze ul. Koszalińskiej, w pobliżu rzeki Wogry, licznie.

Solidago virgaurea L. s. str. - L, T, Połczyn-Zdrój, nasyp kolejowy, bardzo licznie; Połczyn-Zdrój (część SE i SW), łąki przy ogródkach działkowych, licznie; na W od Kołacza, poręba, 6 osobników.

Tanacetum vulgare L. - L, T, na W od Kołacza; Połczyn-Zdrój (część E, SE i W), łąka przy osiedlu Polna, obrzeża miasta, ugory, licznie.

Taraxacum officinale F. H. Wigg. - L, Połczyn-Zdrój, trawniki, park zdrojowy, łąki przylegające do miasta, bardzo licznie; wzdłuż dróg: między Ogartowem a Popielawami i Połczynem--Zdrojem a Kołaczem, licznie.

Tussilago farfara L. - L, Połczyn-Zdrój, park zdrojowy, w sąsiedztwie zalewu, pojedyncze osobniki.

\section{Betulaceae}

Betula pendula Roth - L, Połczyn-Zdrój, park zdrojowy, przy stawie na skarpie, murawa przy cmentarzu komunalnym, pojedyncze osobniki. 


\section{Boraginaceae}

Echium vulgare L. - T, Połczyn-Zdrój (część E, SE i centrum miasta), łąka przy os. Polna oraz przy drogach, licznie.

\section{Brassicaceae}

Capsella bursa-pastoris (L.) Medik. - L, Połczyn-Zdrój (część E, SE i centrum miasta), łąka przy os. Polna oraz przy drogach, licznie; na W od Kołacza, droga do Jeziora Radoniowieckiego, licznie; na N od Kołacza, łąka, licznie.

Sinapis alba L. - L, T, Połczyn-Zdrój (część W), miedze, dość licznie.

Thlaspi arvense L. - T, Połczyn-Zdrój (część SE), ugór na obrzeżach miasta, 4 osobniki.

\section{Caprifoliaceae}

Sambucus nigra L. - L, T, na W od Kołacza, brzeg drogi do Jeziora Radoniowieckiego, 2 osobniki; Połczyn-Zdrój, ul. Reymonta, 4 osobniki; ul. Chopina, 3 osobniki; skrzyżowanie ul. 15 Grudnia i ul. Wojska Polskiego, 2 osobniki; skrzyżowanie ul. Wojska Polskiego i ul. Zdrojowej, 2 osobniki; ul. Solankowa, 3 osobniki; ul Koszalińska, przy stacji benzynowej, 2 osobniki.

\section{Caryophyllaceae}

Agrostemma githago L. - T, Połczyn-Zdrój (część SE), pole uprawne, licznie.

Saponaria officinalis L. - L, T, Połczyn-Zdrój (część SE), łąka przy os. Polna, 5 osobników (ryc. 2).

\section{Clusiaceae}

Hypericum perforatum L. - L, T, Połczyn-Zdrój (część E i SE), ugory, łąki na obrzeżach miasta, licznie.

\section{Convolvulaceae}

Calystegia sepium (L.) R. Br. - L, T, Połczyn-Zdrój, zarośla przy ul. Sobieskiego, pojedyncze osobniki.

\section{Crassulaceae}

Sedum acre L. - L, T, Połczyn-Zdrój (część SE), ogródki działkowe, trawnik na os. Nowa, dość licznie.

\section{Cucurbitaceae}

Bryonia alba L. - L, T, Połczyn-Zdrój (część E), wysypisko śmieci między cmentarzem komunalnym a stadionem miejskim, 10 osobników.

\section{Cupressaceae}

Juniperus communis L. - L, T, droga między Ogartowem a Popielawami na S od Kołacza, skraj lasu, 3 osobniki; Połczyn-Zdrój, ul. Reymonta, 2 osobniki, skrzyżowanie ul. Mieszka I i ul. 15 Grudnia, 1 osobnik. 


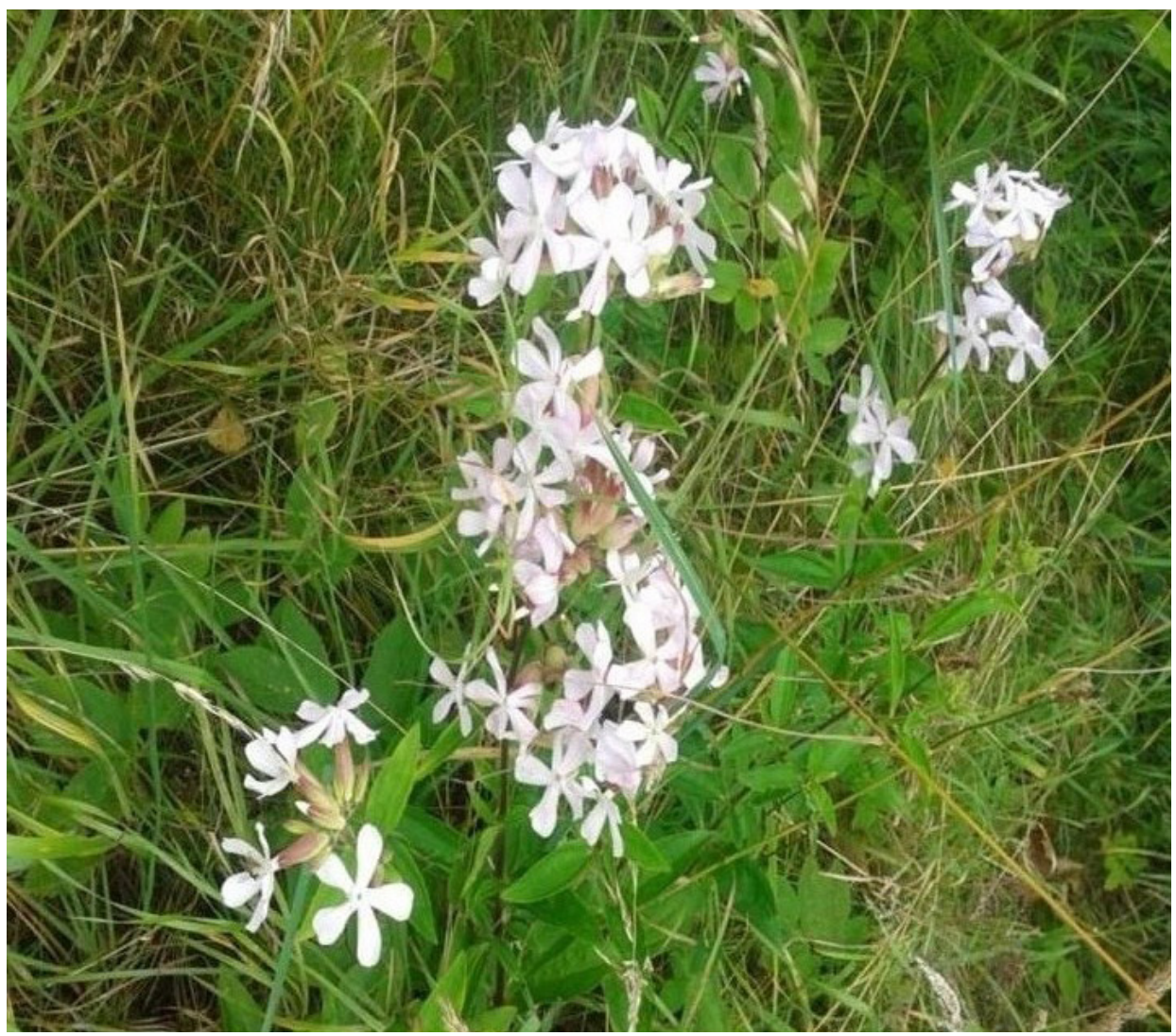

Ryc. 2. Saponaria officinalis L. - łąka przy osiedlu Polna w Połczynie-Zdroju. Fot. P. Radke Fig. 2. Saponaria officinalis L. - meadow near Polna housing estate, Połczyn-Zdrój.

Phot. P. Radke

\section{Equisetaceae}

Equisetum arvense L. - L, T, Połczyn-Zdrój, nasyp kolejowy, przy ogródkach działkowych, zbocze między ul. Nową a ul. Warszawską, park zdrojowy; droga między Ogartowem a Popielawami na S od Kołacza; na W od Kołacza, poręba, dość licznie.

Equisetum telmateia Ehrh. - L, T, Połczyn-Zdrój, park zdrojowy, przy sanatorium Borkowo, dość licznie.

\section{Euphorbiaceae}

Euphorbia cyparissias L. - T, Połczyn-Zdrój (część SE), miedza przy polu uprawnym, licznie.

\section{Fabaceae}

Melilotus officinalis (L.) Pall. - L, T, Połczyn-Zdrój, nasyp kolejowy i przylegające łąki; nasyp kolejowy na $\mathrm{S}$ od Kołacza, nielicznie.

Sarothamnus scoparius (L.) Wimm. - L, T, na W od Kołacza, poręba, 1 osobnik. 


\section{Hippocastanaceae}

Aesculus hippocastanum L. - L, T, Połczyn-Zdrój, przy ul. 15 Grudnia, park zdrojowy, nielicznie.

\section{Lamiaceae}

Lamium album L. - L, Połczyn-Zdrój, park zdrojowy od ul. Sobieskiego, dość licznie.

Lycopus europaeus L. - L, brzeg Jeziora Radoniowieckiego; brzeg zalewu koło Połczyna-Zdroju, pojedyncze osobniki.

Prunella vulgaris L. - L, Połczyn-Zdrój, łąki koło zalewu, dość licznie; na W, S i E od Kołacza, skraje lasów, nielicznie.

\section{Liliaceae}

Convallaria majalis L. - L, T, między Ogartowem a Popielawami na SW od Kołacza, skraj lasu przy drodze, licznie; Połczyn-Zdrój, park zdrojowy, część środkowa przy sanatorium Gryf, licznie; cmentarz komunalny, licznie (ryc. 3).

Maianthemum bifolium (L.) F. W. Schmidt - T, brzeg Jeziora Radoniowieckiego, 10 osobników; Połczyn-Zdrój, park zdrojowy (część SE), przy basenie miejskim, wzniesienie przy Stawie Południowym, licznie.

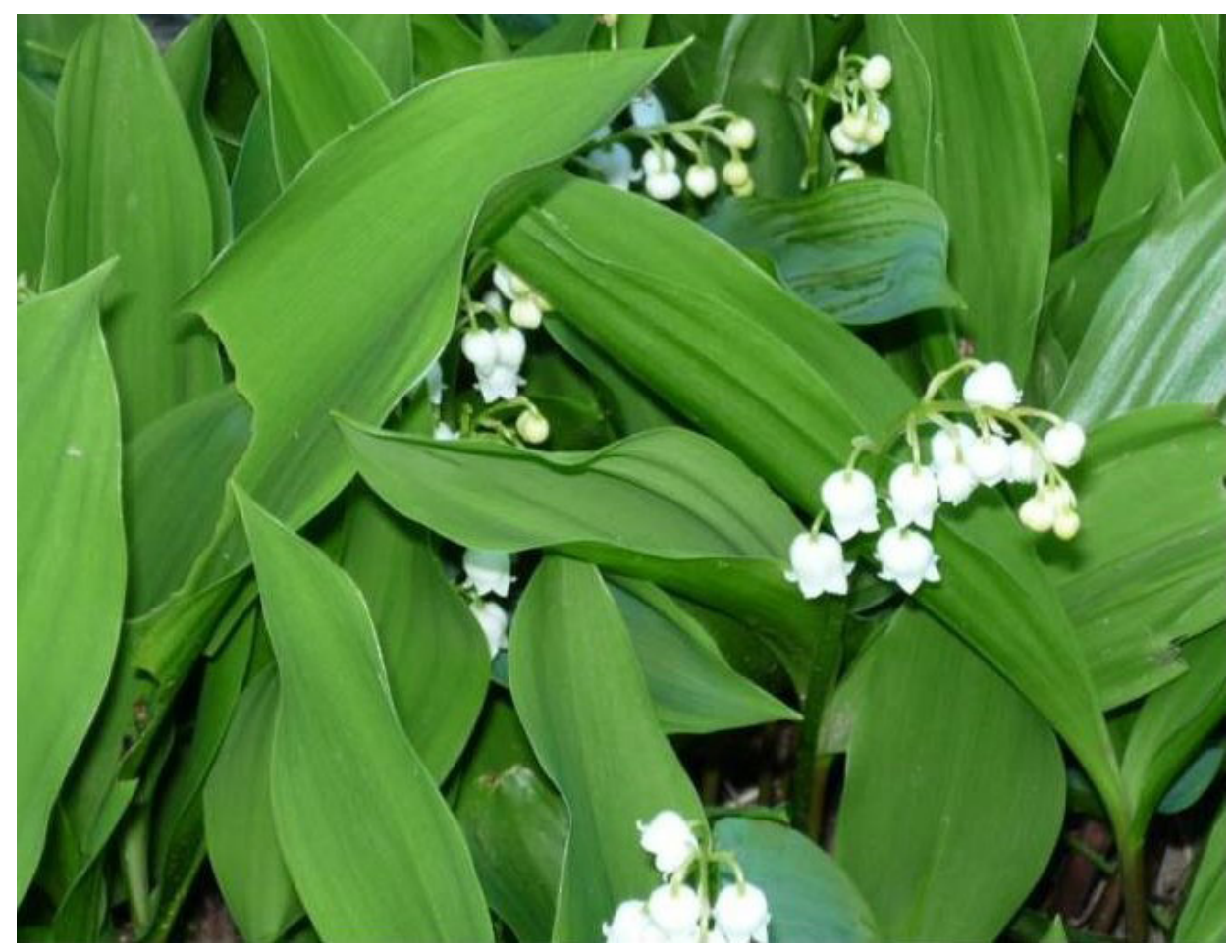

Ryc. 3. Convallaria majalis L. - skraj lasu między Ogartowem a Popielawami. Fot. P. Radke Fig. 3. Convallaria majalis L. - forest edge between Ogartowo and Popielawy.

Phot. P. Radke 


\section{Loranthaceae}

Viscum album L. - L, T, Połczyn-Zdrój (część E i SE), przydrożne drzewa, cmentarz komunalny, licznie.

\section{Papaveraceae}

Chelidonium majus L. - L, T, Połczyn-Zdrój (część W, S i E), ugory, łąki, zarośla w centrum miasta, brzeg drogi, licznie.

Papaver rhoeas L. - L, T, Połczyn-Zdrój (część NE i SE), pola uprawne, licznie.

Papaver somniferum L. - L, T, Połczyn-Zdrój (część SE), wysypisko śmieci przy ogródkach działkowych, nieużytkowany ogródek działkowy, licznie (ryc. 4).

\section{Plantaginaceae}

Plantago lanceolata L. - L, Połczyn-Zdrój, łąki, przydroża, ugory, licznie; na W od Kołacza, przy drodze do Jeziora Radoniowieckiego, pojedyncze osobniki; na N od Kołacza, łąka, licznie.

Plantago major L. s. str. - L, Połczyn-Zdrój, łąki, przydroża, ugory, dość licznie; na W od Kołacza, przy drodze do Jeziora Radoniowieckiego, pojedyncze osobniki; na N od Kołacza, łąka, dość licznie; przy drodze między Połczynem-Zdrojem a Popielawami, dość licznie.

\section{Poaceae}

Elymus repens (L.) Gould - L, Połczyn-Zdrój (część E), pola uprawne, park zdrojowy, dość licznie; na S od Kołacza, pola uprawne, dość licznie; skraje lasów koło Kołacza, licznie.

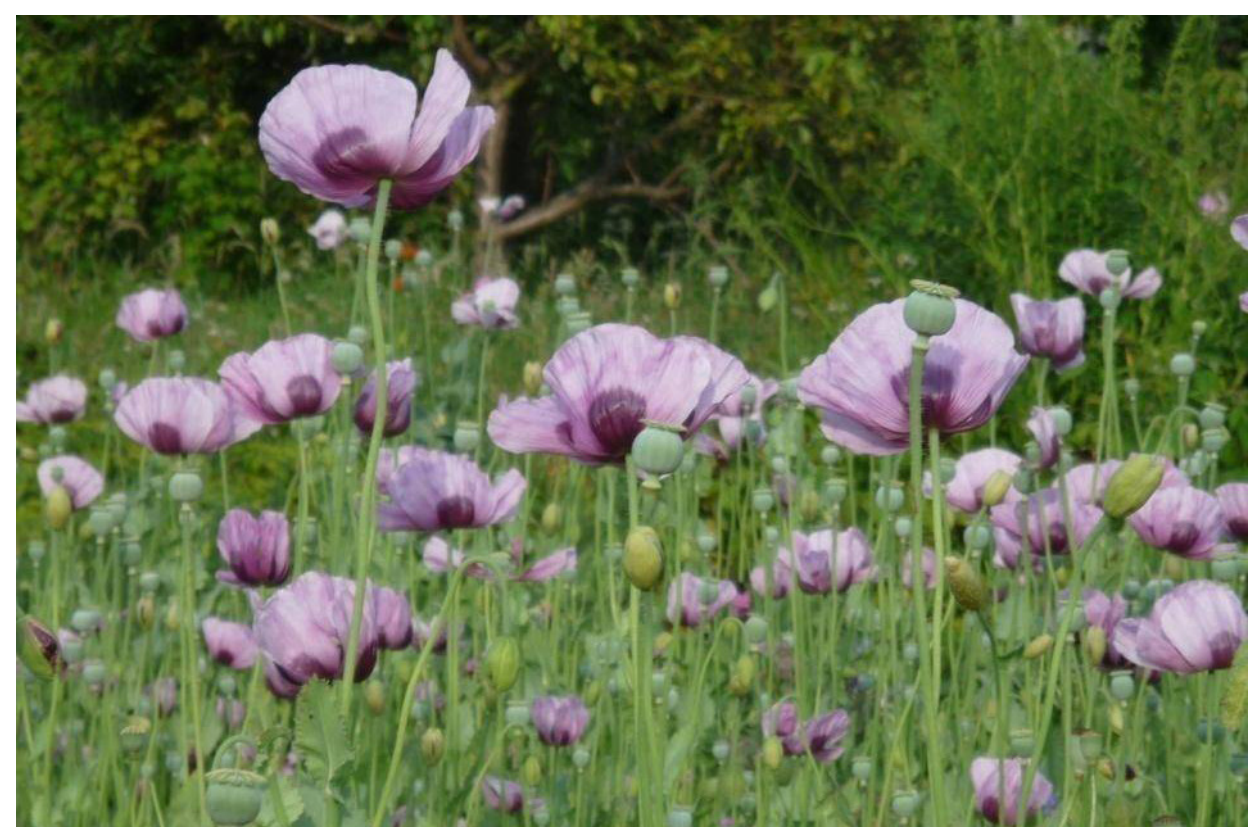

Ryc. 4. Papaver somniferum L. - nieużytkowany ogródek działkowy w Połczynie-Zdroju. Fot. P. Radke

Fig. 4. Papaver somniferum L. - unused garden plot in Połczyn-Zdrój. Phot. P. Radke 


\section{Polygonaceae}

Polygonum aviculare agg. - L, Połczyn-Zdrój, obrzeża miasta, ogródki działkowe, uprawy, między cmentarzem komunalnym a stadionem miejskim, licznie; na W od Kołacza, droga do Jeziora Radoniowieckiego, licznie.

Polygonum hydropiper L. - L, T, Połczyn-Zdrój, uprawy, zarośla za parkiem zdrojowym, nielicznie.

Rumex acetosella L. - T, Połczyn-Zdrój (część E i SE), obrzeża miasta, trawnik przy rondzie, ul. Wojska Polskiego; na N od Kołacza, przy skraju lasu, pola, licznie.

\section{Primulaceae}

Primula veris L. - L, T, Połczyn-Zdrój, zarośla koło cmentarza komunalnego, pojedyncze osobniki.

\section{Ranunculaceae}

Aconitum variegatum L. - T, Połczyn-Zdrój (część S), rów między drogą a ogródkami działkowymi, 2 osobniki.

Ficaria verna Huds. - T, na W od Kołacza, droga do Jeziora Radoniowieckiego, 5 osobników; Połczyn-Zdrój, park zdrojowy (część SW), trawniki przy ul. 22 Lipca, plac 1000-lecia Państwa Polskiego, licznie.

Ranunculus repens L. - T, droga między Ogartowem a Popielawami na S od Kołacza, skraj lasu na W od Kołacza, licznie; Połczyn-Zdrój, teren parku zdrojowego (część SW), trawniki przy ul. Warszawskiej, droga od ul. Strażackiej do ogródków działkowych (część E), licznie.

\section{Rhamnaceae}

Frangula alnus Mill. - L, przy drodze między Ogartowem a Popielawami na S od Kołacza, 2 osobniki.

\section{Rosaceae}

Agrimonia eupatoria L. - L, Połczyn-Zdrój (część SE), łąka przy os. Polna, 2 osobniki.

Crataegus monogyna Jacq. - L, Połczyn-Zdrój, ul. Reymonta, ścieżka rowerowa na NW od Połczyna-Zdroju, dość licznie; między Ogartowem a Kołaczem, skraj lasu, pojedyncze osobniki.

Fragaria vesca $\mathrm{L}$. - L, las na NW od Kołacza, nielicznie.

Geum urbanum L. - L, na W od Kołacza, poręba, 5 osobników.

Potentilla anserina L. - L, Połczyn-Zdrój (część SW), pole uprawne, os. Kazimierza Wielkiego, trawnik przy ul. Traugutta, dość licznie; na W od Kołacza, droga do Jeziora Radoniowieckiego, nielicznie.

\section{Rubiaceae}

Galium odoratum (L.) Scop. - L, T, Połczyn-Zdrój, brzegi rowów przy ul. Sobieskiego, bardzo licznie.

\section{Scrophulariaceae}

Linaria vulgaris Mill. - L, T, Połczyn-Zdrój (część E), wysypisko śmieci między cmentarzem komunalnym a stadionem miejskim; na W od Kołacza, przy drodze do Jeziora Radoniowieckiego, pojedyncze osobniki. 


\section{Solanaceae}

Datura stramonium L. - T, Połczyn-Zdrój (część E), wysypisko śmieci między cmentarzem komunalnym a stadionem miejskim, 8 osobników.

Solanum dulcamara L. - T, Połczyn-Zdrój (część SE), ogródki działkowe, 2 osobniki.

\section{Tiliaceae}

Tilia cordata Mill. - L, Połczyn-Zdrój, wzdłuż ul. Warszawskiej i ul. Strażackiej, park zdrojowy, nielicznie.

\section{Urticaceae}

Urtica dioica L. - L, Połczyn-Zdrój, zarośla między parkiem zdrojowym a ul. Sobieskiego, przy ogródkach działkowych, przy nasypie kolejowym, licznie; skraje lasów koło Kołacza, dość licznie.

\section{Violaceae}

Viola tricolor agg. - L, Połczyn-Zdrój (część SE), odłogi przy ogródkach działkowych, dość licznie; na W od Kołacza, poręba, pojedyncze osobniki.

\section{DYSKUSJA}

Wstępne badania flory terenu miasta Połczyn-Zdrój i jego okolic wykazały obecność wielu gatunków roślin leczniczych i trujących. Spośród 69 taksonów najwięcej odnotowano roślin leczniczych oraz gatunków o właściwościach zarówno leczniczych, jak i trujących. Ogółem stanowiły one 84\% stwierdzonych taksonów. Rośliny mające właściwości wyłącznie toksyczne, mimo że nie były liczną grupą, jednak mogą stwarzać istotne niebezpieczeństwo, gdyż w większości rosną w bliskim sąsiedztwie człowieka. Tylko nieliczne z nich występują na dalej położonych terenach. Gatunki takie jak np.: Frangula alnus, Artemisia absinthium i Sarothamnus scoparius są obecne wyłącznie na obszarze znacznie oddalonym od miasta, w lasach i na porębach. Odnotowano duże skupiska Convallaria majalis, która jeszcze do 2014 r. podlegała ochronie częściowej (Rozporządzenie Ministra..., 2004). Roślina ta jest bogatym źródłem glikozydów nasercowych (Lamer-Zarawska, Niedworok 2007). Niepokojący jest fakt obecności na terenie miejskim gatunków takich, jak: Aconitum variegatum, Datura stramonium czy Papaver somniferum. Występują one najczęściej na wysypiskach lub w okolicach ogródków, co wskazuje na to, że nieodpowiedzialne wyrzucanie odpadów organicznych z ogrodów, działek czy cmentarzy sprzyja ich rozsiewaniu. Rośliny te są bardzo szkodliwe dla zdrowia człowieka. Mak lekarski P. somniferum zawiera alkaloidy izochinolinowe (papaweryna, kodeina, morfina), które wpływają depresyjnie na układ oddechowy, obniżają tętno, mogą powodować halucynacje i pobudzenie ruchowe (Henneberg, 
Skrzydlewska 1984). Bieluń D. stramonium wytwarza alkaloidy skopolaminę, hioscyjaminę i atropinę. Są one niebezpieczne, gdyż po dostaniu się do organizmu wywołują halucynacje, tachykardię i zatrzymanie oddechu (Burda 1998). Bardzo silnym alkaloidem jest akonityna z tojadu $A$. variegatum, która zaburza pracę serca i układu oddechowego (Wiłkomirski 2015). Spośród stwierdzonych na badanym terenie taksonów groźnymi dla organizmu ludzkiego mogą być także rośliny zawierające toksyczne olejki eteryczne zasobne w tujon, takie jak Tanacetum vulgare i Artemisia absinthium (Ożarowski, Jaroniewski 1987). Po ich spożyciu może dochodzić do uszkodzenia nerek, wątroby, tkanki nerwowej oraz do poronień (Henneberg, Skrzydlewska 1984). Zawarte w Artemisia absinthium laktony sekswiterpenowe (absyntyna i anabsyntyna), przy odpowiednim dawkowaniu, powodują wzmożone wydzielanie śliny i kwasu żołądkowego, działają też rozkurczowo (Lamer-Zarawska, Niedworok 2007). Podobne działanie wykazuje Hypericum perforatum, który stosowany jest w preparatach żółciotwórczych, przy problemach trawiennych oraz jako środek uspokajający (Kohlmünzer 2003). Olejek z H. perforatum wywołuje również działanie niepożądane, jakim jest fotouczulenie. Z kolei podrażnienia skóry i błony śluzowej powoduje sok mleczny z Chelidonium majus (Mowszowicz 1982). Saponiny z Agrostemma githago i Saponaria officinalis oraz substancje terpenowe z Bryonia alba działają drażniąco na układ pokarmowy, wywołując ślinotok, bóle brzucha, biegunkę i wymioty (Burda 1998). Występowanie tych roślin w bliskim sąsiedztwie terenów osadniczych, wręcz w centrum miasta, stwarza realne zagrożenie możliwością zatrucia ludzi i zwierząt. Skalę tych zagrożeń jest trudno określić, gdyż zasoby roślin trujących, a także leczniczych gminy i miasta Połczyn-Zdrój należą do stosunkowo słabo poznanych, zatem wskazane są dalsze ich badania.

\section{LITERATURA}

Borówka R. K. (2002): Środowisko geograficzne. [W:] Borówka R. K., Friedrich S., Heese T., Jasnowska J., Kochanowska R., Opęchowski M., Stanecka E., Zyska W. i in. Przyroda Pomorza Zachodniego: 6-105. Oficyna in Plus. Szczecin.

Burda P. R. (1998): Zatrucia ostre grzybami i roślinami wyższymi. Ss. 356. Wyd. Nauk. PWN. Warszawa.

Henneberg M., Skrzydlewska E. (red.). (1984): Zatrucia roślinami wyższymi i grzybami. Ss. 390. PZWL. Warszawa.

Kaźmierczakowa R., Bloch-Orłowska J., Celka Z., Cwener A., Dajdok Z., Michalska-Hejduk D., Pawlikowski P., Szcześniak E., Ziarnek K. (2016): Polska czerwona lista paprotników i roślin kwiatowych. - Polish red list of pteridophytes and flowering plants. Ss. 44. Instytut Ochrony Przyrody PAN. Kraków.

Kohlmünzer S. (2003): Farmakognozja. Podręcznik dla studentów farmacji. Wyd. V. Ss. 290. Wyd. Lek. PZWL. Warszawa.

Kondracki J. (2002): Geografia regionalna Polski. Ss. 441. Wyd. Nauk. PWN. Warszawa.

Koźmiński C., Michalska B., Czarnecka M. (2007): Klimat województwa zachodniopomorskiego. Ss. 147. AR Szczecin, Uniwersytet Szczeciński. Szczecin. 
Lamer-Zarawska E., Niedworok J. (2007): Fitoterapia. Terapeutyczne zastosowanie surowców zielarskich i ich składników. [W:] Lamer-Zarawska E., Kowal-Gierczak B., Niedworok J. (red.). Fitoterapia i leki roślinne: 109-368. Wyd. Lek. PZWL. Warszawa.

Mirek Z., Piękoś-Mirkowa H., Zając A., Zając M. (2002): Flowering plants and pteridophytes of Poland. A checklist. Ss. 442. W. Szafer Inst. of Bot., Polish Acad. of Sci. Kraków.

Morazzoni P., Bombardelli E. (1995): Silybum marianum (Carduus marianus). Fitoterapia, 66(1): 3-42.

Mowszowicz J. (1982): Przewodnik do oznaczania krajowych roślin trujących i szkodliwych. Ss. 480. PWRiL. Warszawa.

Mowszowicz J. (1990): Rośliny trujące. Atlas. Ss. 224. WSiP. Warszawa.

Ożarowski A., Jaroniewski W. (1987): Rośliny lecznicze i ich praktyczne zastosowanie. Ss. 436. Inst. Wyd. Związków Zaw. Warszawa.

Rozporządzenie Ministra Środowiska z dnia 9 lipca 2004 r. w sprawie gatunków dziko występujących roślin objętych ochroną. Dz.U. Nr 168, poz. 1764 i 1765.

Rozporządzenie Ministra Środowiska z dnia 9 października 2014 r. w sprawie ochrony gatunkowej roślin. Dz.U. 2014, poz. 1409.

Rutkowski L. (2004): Klucz do oznaczania roślin naczyniowych Polski niżowej. Wyd. 2. Ss. 814. Wyd. Nauk. PWN. Warszawa.

Sen S., Chakraborty R., Sridhar C., Reddy Y.S.R., De B. (2010): Free radicals, antioxidants, diseases and phytomedicines: current status and future prospect. Intern. Journal of Pharm. Sci. Rev. and Res., 3(1): 91-100.

Sies H. (1991): Oxidative Stress Introduction. [W:] Sies H. (ed.). Oxidative Stress: Oxidants and Antioxidants: 15-22. Academic Press. London.

Wiłkomirski B. (2015): Toksyczny świat. Zarys historii trucizn. Ss. 192. Kieleckie Tow. Nauk. Kielce.

\section{POISONOUS AND MEDICINAL PLANTS OF POŁCZYN-ZDRÓJ AND ITS SURROUNDING AREA (THE DRAWA LAKELAND DISTRICT) - PRELIMINARY STUDIES}

\section{Sum mary}

The studies, whose aim was to determine the distribution and resources of medicinal and poisonous plants within the area of Połczyn-Zdrój and its surroundings, were conducted from March to October 2015. As a result, 69 species of vascular plants were identified. The largest group - 30 taxa consisted exclusively of medicinal plants. Among them, the most numerous were such plants as.: Elymus repens, Plantago lanceolata, P. major and Polygonum aviculare. Equally species-rich group comprised the plants with both medicinal and poisonous properties. It was represented by 28 taxa, e.g. a great number of: Chelidonium majus, Hypericum perforatum, Papaver somniferum and Tanacetum vulgare. Eleven species with exclusively poisonous properties were recorded, the most numerous: Echium vulgare and Maianthemum bifolium. Among all identified plants only - Agrostemma githago is included in the Polish red list of pteridophytes and flowering plants (Kaźmierczakowa et al. 2016), and Aconitum variegatum is under partial protection (Rozporządzenie Ministra..., 2014). Despite the fact that the group of plants with toxic properties was not very large, these plants may pose a real threat to people since they grow in their immediate vicinity. 